\title{
Analysis of the Impact of Coronavirus Outbreak on the Nigerian Economy
}

\author{
Rabiu Maijama'a ${ }^{1,2, ~}$, Kabiru Saidu Musa ${ }^{1}$, Ahmad Ammani Isah $^{1}$, Samaila Adamu ${ }^{3}$ \\ ${ }^{1}$ Department of Economics, Faculty of Social and Management Sciences, Bauchi State University Gadau, Yuli Campus, Bauchi, Nigeria \\ ${ }^{2}$ Nageria National Petroleum Corporation, NNPC Towers, Central Business District, Garki Abuja, Nigeria \\ ${ }^{3}$ Department of Economics and Development Studies, Faculty of Humanities, Management and Social Sciences, Federal University Kashere, \\ Gombe, Nigeria
}

\section{Email address:}

rabiu.wunti@yahoo.com (R. Maijama’a),kabirusaidumusa@gmail.com (K. S. Musa), ahmadisahammani@gmail.com (A. A. Isah), adamusamaila99@gmail.com (S. Adamu)

*Corresponding author

\section{To cite this article:}

Rabiu Maijama'a, Kabiru Saidu Musa, Ahmad Ammani Isah, Samaila Adamu. Analysis of the Impact of Coronavirus Outbreak on the Nigerian Economy. American Journal of Environmental and Resource Economics. Vol. 5, No. 2, 2020, pp. 39-43. doi: $10.11648 /$ j.ajere.20200502.13

Received: March 24, 2020; Accepted: April 9, 2020; Published: April 30, 2020

\begin{abstract}
The study examine the impact of corona virus outbreak on the Nigerian economy using reports from Nigeria Centre for Disease Control and World Health organization for the period of $11^{\text {th }}$ March to $19^{\text {th }}$ March 2020 on total cases of the virus in Nigeria. According to the WHO, the virus has infected about 76,936 people in the mainland China, with additional 2,051 cases of the virus from about 30 other countries and in Nigeria there are total of 91 people been screened for COViD-19 (22 new) in 13 state (Edo, Ekiti, Enugu, FCT, Kano, Lagos, Ogun, Rivers, Yobe, Katsina, Akwa Ibom, Nasarawa and Ondo) out of which 63 tested negative and have been ruled out, result is pending for 17, while 11 were confirmed positive. Base on the reported cases of the disease, the researchers therefore recommend that precautionary measures that include Regularly and thoroughly wash your hands with soap and water, and use hand sanitizer, maintain at least one and half metres distance between yourself and anyone who is coughing or sneezing, persons with persistent cough or sneezing should stay home or keep a social distance, but not mix in crowd and making sure you and people around you, follow good respiratory hygiene, meaning cover your mouth and nose with a tissue or into your sleeve at the bent elbow or tissue when you cough or sneeze and then dispose of the used tissue immediately among others should be taken in consideration.
\end{abstract}

Keywords: Coronavirus, Nigeria Economy, Nigeria Centre for Disease Control, WHO and Crude Oil Price

\section{Introduction}

On the last day of December 2019, the World Health Organizations' (WHO) China office received the first reports of an earlier unknown virus. It had generated a number of pneumonia cases in Wuhan which is the capital of Hubei region in Central China, with a population of over 11 million people. The virus, which has been renamed as Coronavirus Disease in the year 2019 or COVID-19 (it was formerly known as the 2019-nCoV acute respiratory disease) by the World Health Organization, the virus has infected about 76,936 people in the mainland China, with additional 2,051 cases of the virus from about 30 other countries [1].
By just looking at the number of total cases of coronavirus and the figures of the affected countries does not tell the whole story of 118,142 total cases with 4,264 deaths and accounted worldwide in 114 countries which signifies that more than 90 percent of the total cases of the virus are in just 4 countries, and two of those of China and the Republic of Korea have significantly declining epidemics, 81 countries have not reported any cases of the virus, and the 57 other countries have revealed 10 cases of the virus or less [2, 3]. The Table 1 below provides the detail information about the disease ranging from total cases of the disease, total deaths due to the disease and the total recovery figures from 15 countries around the world including Nigeria as at 11 March 
2020. [4]

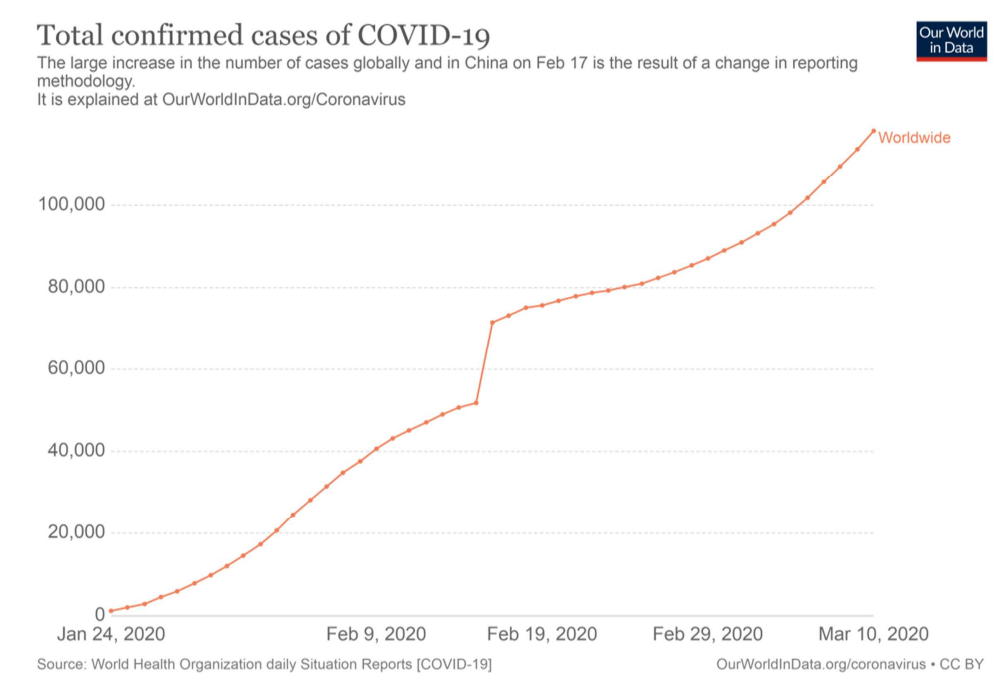

Figure 1. WHO (2020) Total Confirmed Cases of the Virus in the countries around the World.

Table 1. Active Cases of Coronavirus around the world.

\begin{tabular}{lllll}
\hline N/S & Countries & Total cases & Total Deaths & Recovered \\
\hline 1 & China & 80,932 & 3,172 & 62,820 \\
2 & Italy & 12,462 & 827 & 1,045 \\
3 & Iran & 10,075 & 354 & 3,276 \\
4 & South Korea & 7,869 & 66 & 333 \\
5 & France & 2,284 & 48 & 12 \\
6 & Spain & 2,277 & 47 & 189 \\
7 & Germany & 2,078 & 3 & 25 \\
8 & USA & 1,323 & 30 & 15 \\
9 & UK & 590 & 10 & 18 \\
10 & Switzerland & 652 & 4 & 4 \\
11 & Japan & 639 & 15 & 118 \\
12 & Algeria & 24 & 1 & 8 \\
13 & South Africa & 13 & - & - \\
14 & Egypt & 67 & 1 & 27 \\
15 & Nigeria & 2 & - & - \\
\hline
\end{tabular}

In the past few weeks, the number of cases of COVID-19 around the world apart from China as earlier done by [5] and shown by [6] has increased 13-fold, and the number of affected countries has tripled. There are now more than
118,000 cases of the virus in 114 countries, and 4,291 people have lost their lives and thousands more are struggling for their lives in hospitals. In the days and weeks to come, the expectation regarding the number of cases, the number of deaths, and the numbers of affected countries rise even higher. WHO has been evaluating this epidemic around the clock and they are extremely worried both by the increasing spread stage and harshness, and also by the increasing levels of inaction. In $10^{\text {th }}$ March 2020, WHO made it clear that the COVID-19 can be described as a Global pandemic and a Pandemic is not a word to use evenly or carelessly but it is a word that, if misused, can cause unreasonable fear, or unfair acceptance that the fight against the virus is over, leading to needless suffering and death. Describing the situation as a pandemic does not change organization's consideration of the danger posed by this virus and It does not change what the organization and countries should do [2]. The figure 2 below shows the total number of deaths worldwide due to corronavirus disease from $20^{\text {th }}$ January to $10^{\text {th }}$ March 2020.

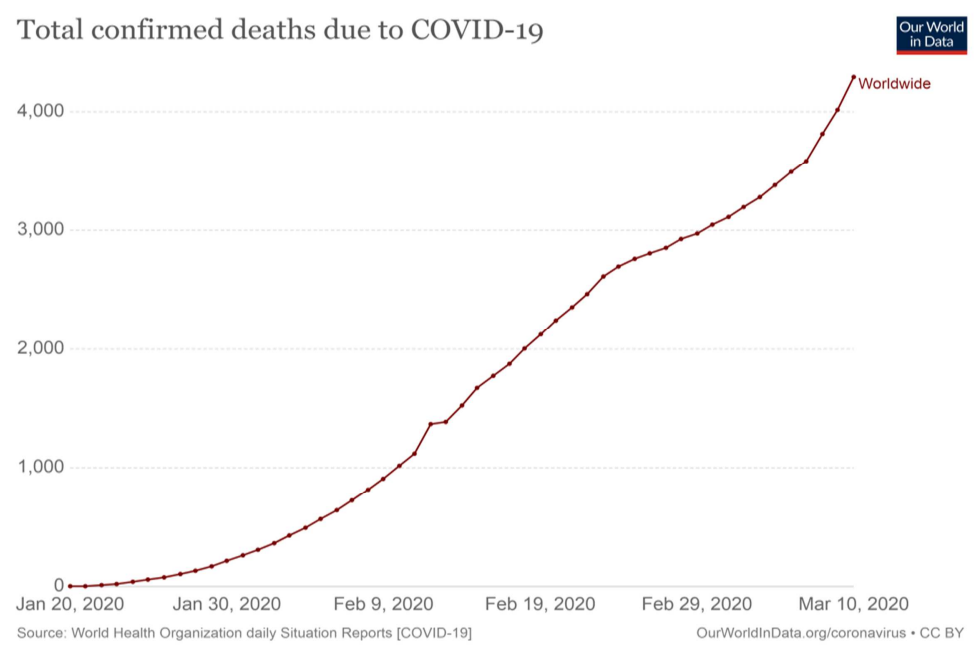

Figure 2. WHO (2020), Total Confirmed Deaths due to Corona Virus around the World. 


\section{COVID 19, Crude Oil Price and the Nigerian Economy}

The International Monetary Fund has cut its projection for Nigeria's 2020 economic growth to $2 \%$ from $2.5 \%$ due to plunging oil prices stemming from the coronavirus outbreak. The West African nation is the continent's biggest producer and depends on crude for $90 \%$ of its exports. Nigeria will need at least three months to clear a production backlog even if crude prices recover, NNPC Managing Director and the chief executive officer of state-owned Nigerian National Petroleum Corporation as the country has 50 unsold cargoes and they are with the hoped that the oil price drop may have seen the bottom already. Nigeria's fiscal and monetary authorities will announce measures in coming days to deal with the economic fallout from the coronavirus outbreak Guardian [7].

The oil price shock due to the coronavirus came as a great surprise to the Nigerian government and the impact has put significant strain on the budget and the currency and the government may have to adjust its 2020 budget, which was based on a crude price of $\$ 57$ a barrel according to the finance minister. Already, oil prices which are the mainstay of the country are trading below the Federal Government's benchmark for the 2020 budget, thus posing a threat to the budget which was signed by President Muhammadu Buhari in December, on the assumption of oil production of 2.18 million barrels per day with the price benchmark of $\$ 57$ per barrel the Guardian [7].

Similarly, Nigeria's latest Excess Crude Account balance, according to a statement from the Office of the Accountant General of the Federation, was put at $\$ 71.81 \mathrm{~m}$, while movement in reserves showed that the country's reserves stood at $\$ 36.37$ billion at the weekend, down by $\$ 2.16$ billion from $\$ 38.53$ billion in which it opened the year With an earlier projection by Citigroup that Brent Crude might slide to as low as $\$ 47$ a barrel in the wake of the coronavirus that is yet to be contained, there are concerns about the economy's buffer package and oil prices are expected to tank further having dropped to $\$ 49.67$ and the Federal Government has been exploring various means of generating revenue to buffer the effect of unstable oil prices through increment in VAT and review of extant legislation, among others Guardian [7, 8].

The naira is still a classic petrocurrency whose fate is determine by the international oil prices, at least with no unstable shift in economic structure. That shift isn't a shortrun task and at the moment, the position by Nigeria's key economic indicators to guard the naira will probably be tested by the anticipated additional decline in Nigeria's foreign exchange reserves and the Central Bank of Nigeria set a $\$ 30$ billion foreign exchange reserves entry for devaluation. Nigeria is treacherously close. A slump in foreign reserves from $\$ 38$ billion to $\$ 30$ billion in Nigeria will occur just as dramatically. Nigeria's foreign exchange reserves are there to assist the Central Bank protect the naira's value; Central bank can sell foreign exchange reserves to purchase their local currencies in an effort to defend the currency's value. This action depends on the provision of foreign exchange reserves, and any action taken by CBN might really provide an indicator to foreign investors of impending devaluation. The sequence would be provoked if foreign shareholders begin to quit Nigerian equities and bonds all together. If the central bank plan fails and Nigeria runs tremendously low on foreign reserves, the Naira might decrease in value, permitting entrepreneurs to arbitrage. Nigeria's gross foreign exchange reserves are at the same level approximately $\$ 38$ billion as they were in 2014 and 2015 years when oil prices as well fell sharply compare both periods with the $\$ 53$ billion in foreign reserves. Nigeria had in 2008, at the height of the international financial crisis, and that still incurred a serious economic charge on Nigeria [9].

Devaluation would cause rise in importation costs for raw materials, soft and hard commodities that are payable for using foreign exchange reserves. Raw materials for industries will become more costly and eventual losers will be daily consumers who will notice more erosion in their purchasing power. Central Bank involvement to regulate the value of Naira is almost sure if foreign exchange reserves run less than the threshold limit. What's an even bigger unknown is whether or not such involvement will be greatly preventative as the existing official exchange rate is the longest-term of strength that Nigeria's foreign exchange reserves regime has had in decades. Recently, low interest rates in advanced economies have permitted $\mathrm{CBN}$ to reduce its interest rates locally, however if prices of crude oil keep on coming under difficulty, depositing additional pressure on the naira, there'll be pressure to increase the rates. The mixture of increasing inflation that is presently at about 12 percent and naira devaluation danger could force the Central Bank's hand on rates. All of Nigeria's 2020 budget indicators ranging from oil production volume of 2.18 million barrels per day, oil benchmark of $\$ 57$ per barrel, $\$ 305$ exchange rate of naira per US dollar, GDP growth rate of 2.93 percent, and inflation rate of 10.81 percent presently seems out of reach, and will most likely lead to downsizing of expenditure plans in 2020 [9].

\section{COVID-19 Cases and the Affected States Across the Country}

The Federal Ministry of Health has confirmed ten (10) new cases of the coronavirus disease i.e. COVID-19 in Nigeria; three (3) new cases in the Federal Capital Territory (FCT) and seven (7) new cases in Lagos State. This brings the total number of confirmed cases in Nigeria to twenty two (22). All ten (10) new cases are Nigerian nationals while Nine (9) of them have travel history to the United Kingdom, Spain, Netherlands, Canada and France. They returned to the country in the last one week. The 10th case is a close contact of a previously confirmed case. The three (3) cases in the FCT are being treated at the University of Abuja Teaching Hospital (UATH), Gwagwalada while the seven (7) new 
cases in Lagos are being treated at the Infectious Disease Hospital (IDH), Yaba. All ten (10) new cases have mild to moderate symptoms and are currently receiving treatment. [10].

As at the 21st of March 2020, twenty two (22) cases have been confirmed, two cases have been discharged and there has been no death from COVID-19 in Nigeria. The Federal Government of Nigeria remains committed to working with states to provide optimal care for all COVID-19 confirmed cases in the country. Contact tracing is ongoing to identify all persons who have been in contact with the new confirmed cases. The Port Health Services of the Federal Ministry of Health has heightened screening at all air, land and sea points of entry into Nigeria and adapted the protocols to reflect the travel guidance issued by the Presidential Task Force on Coronavirus [11]. The National Emergency Operations Centre led by the Nigeria Centre for Disease Control supported by partners continues to coordinate response activities and strengthen preparedness capacity across states nationwide. An intensive national risk communications campaign is ongoing to inform Nigerians about COVID-19. The Federal Ministry of Health working closely with states and the Presidential Task Force on COVID-19 continues to review response activities and institute measures to protect the health of Nigerians [12].

The Table 2 below shows the total cases of COVID-19 and the various states that are affected by the disease across the country. On the 19th March 2020, four new confirmed cases of COVID-19 recorded in Nigeria and cumulatively, Nigeria has recorded twelve (12) confirmed cases of COViD-19 and all the four new cases are from Lagos. Apart from the index case, a total of 91 people have been screened for COViD-19 (22 new) in 13 state (Edo, Ekiti, Enugu, FCT, Lagos, Ogun, Rivers, Yobe, Katsina, Akwa Ibom, Nasarawa and Ondo) out of which 63 tested negative and have been ruled out, result is pending for 17, while 11 were confirmed positive [12].

Table 2. Summary of COVID-19 Cases in Nigeria.

\begin{tabular}{|c|c|c|c|c|c|c|c|}
\hline $\begin{array}{l}\text { States } \\
\text { Affected }\end{array}$ & $\begin{array}{l}\text { No. of People } \\
\text { screened (previously) }\end{array}$ & $\begin{array}{l}\text { No. of People } \\
\text { screened (Last 24hrs) }\end{array}$ & $\begin{array}{l}\text { Total } \\
\text { screened }\end{array}$ & $\begin{array}{l}\text { No. Cases (Lab } \\
\text { Confirmed) }\end{array}$ & $\begin{array}{l}\text { No. of Cases } \\
\text { (on admission) }\end{array}$ & $\begin{array}{l}\text { No. } \\
\text { Discharged }\end{array}$ & No. of Deaths \\
\hline Edo & 1 & 0 & 1 & 0 & 0 & - & 0 \\
\hline A/Ibom & 0 & 1 & 1 & 0 & 0 & - & 0 \\
\hline Enugu & 1 & 0 & 1 & 0 & 0 & - & 0 \\
\hline FCT & 15 & 1 & 16 & 0 & 0 & - & 0 \\
\hline Kano & 1 & 1 & 2 & 0 & 0 & - & 0 \\
\hline Lagos & 44 & 12 & 56 & 9 & 8 & - & 0 \\
\hline Ogun & 4 & 0 & 4 & 2 & 1 & 1 & 0 \\
\hline Nasarawa & 0 & 5 & 5 & 0 & 0 & - & 0 \\
\hline Rivers & 1 & 0 & 1 & 0 & 0 & - & 0 \\
\hline Yobe & 1 & 0 & 1 & 0 & 0 & - & 0 \\
\hline Ekiti & 1 & 0 & 1 & 1 & 0 & - & 0 \\
\hline Katsina & 0 & 1 & 1 & 0 & 0 & - & 0 \\
\hline Ondo & 0 & 1 & 1 & 0 & 0 & - & 0 \\
\hline Total & 69 & 22 & 91 & 12 & 9 & 1 & 0 \\
\hline
\end{tabular}

Sources: Nigeria Centre for Disease control from $19^{\text {th }}$ March, 2020.

\section{Measures to Prevent the Spread of COVID-19 According to the Nigeria Centre for Disease Control}

It is important that Nigerians strictly adhere to social distancing and other necessary precautions in place. These measures include taking the following 11 precautions below to protect yourself and your family:

1. Regularly and thoroughly wash your hands with soap and water, and use alcohol-based hand sanitiser.

2. Maintain at least one and half metres (i.e. 5 feet) distance between yourself and anyone who is coughing or sneezing.

3. Persons with persistent cough or sneezing should stay home or keep a social distance, but not mix in crowd.

4. Make sure you and people around you, follow good respiratory hygiene, meaning cover your mouth and nose with a tissue or into your sleeve at the bent elbow or tissue when you cough or sneeze. Then dispose of the used tissue immediately.
5. Stay home if you feel unwell with symptoms like fever, cough and difficulty in breathing. Please call NCDC toll free number which is available day and night, for guidance on 0800-970000-10. Do not engage in selfmedication

6. Avoiding/postponing events with large gatherings of people including schools, workplaces, places of worship, crowded supermarkets and pharmacies, social and sporting events.

7. Persons with a persistent cough or sneezing, should stay at home until they recover

8. Make sure you and people around you observe hand and respiratory hygiene by:

i. Covering your nose with tissue when sneezing or coughing. Immediately dispose of tissue in a covered bin and wash your hands with soap and water. Use an alcohol-based sanitiser if no water and soap is available

ii. Coughing or sneezing into the sleeve of your bent elbow if no tissue is available.

9. Avoid all non-essential travel to all countries 
10. Stay informed on the latest developments about COVID-19 through official channels on TV and Radio, including the Lagos State Ministry of Health, NCDC and Federal Ministry of Health.

11. Using as much natural vitamin $\mathrm{C}$ as possible will help in strengthen the human body immune system since currently there is no cure for the disease [13].

\section{References}

[1] World Health Organization (2020) Press Conference on Novel Coronavirus Outbreak.

[2] WHO Director General's Opening Remarks at the Media Briefing on COVID-19 $11^{\text {th }}$ March, 2020.

[3] Max, R., Hannah, R and Esteban, O. (2020) "Coronavirus Disease (COVID-19) "Published online at Our World In Data. Retrieved from:' https://ourworldindata.org/coronavirus'.

[4] Corona Virus Cases from Countries Around the World were Obtained from Worldometer Website Available at https://www.worldometers.info/coronavirus/coronavirus-cases/.

[5] Maijama'a, R., Musa, K. S., Garba, A. and Baba, U. M. (2020), Coronavirus Outbreak and the Global Energy Demand: A case of People's Republic of China, American Journal of Environmental and Resource economics, 5 (1): 1013. Doi: 10.11648/j.ajere.20200501.12.

[6] Data on China population on COVID-19 Cases is obtained at
National Bureau of Statistics of China. Available at http://www.stats.gov.cn/english/.

[7] Femi, A., Adeyemi, A., Sulaimon, S., Benjamin, A. and Bankole, O. (2020) How Coronavirus Outbreak Threatens Nigeria's Economy, the Guardian News. Available at https://guardian.ng/news/how-coronavirus-outbreak-threatensnigerias-economy.

[8] Anthony, O., John, A. and Helen, O. (2020) CBN Releases Measures to Battle Economic Impact of Coronavirus, Report Available at https://t.guardian.ng/news/cbn-releases-measuresto-battle-economic-impact-of-coronavirus/.

[9] Rolake, A. F. (2020) How Coronavirus and the Global Oil Price can Impact Nigeria. Available at https://www.theafricareport.com/24442/how-coronavirus-andthe-global-oil-price-war-can-impact-nigeria/.

[10] Nigeria Centre for Disease Control February 28, 2020, First Case of Corona Virus Disease Confirmed in Nigeria, Report Available at https://ncdc.gov.ng/news/227/first-case-ofcorona-virus-disease-confirmed-in-nigeria.

[11] Nigeria Centre for Disease Control $21^{\text {st }}$ March, 2020-Ten New Cases of COVID-19Confirmed in Nigeria Report Available athttps://ncdc.gov.ng/news/237/update-on-covid-19-in-nigeria.

[12] Nigeria Centre for Disease Control Situation Report for $19^{\text {th }}$ March, 2020 on "COVID-19 Outbreak in Nigeria" Pages 1-3. Available at www.ncdc.gov.ng.

[13] Adamu, M. T. (2020) Important Notice Regarding Coronavirus or COVD-1 b9 from Department of Microbiology, Faculty of Science, Gombe State University. 